\title{
Subject-Specific Learning Versus Jewish-Developmental Outcomes in Jewish Education: What Should We Aim For?
}

Jeffrey S. Kress and Jon A. Levisohn

Tow should we think about the desired learning outcomes in Jewish educational

1 settings? Should we frame them primarily in terms of specific subjects, such as Talmud or Hebrew or Jewish history, or even in terms of specific domains of practice like reading Torah or Israeli dance? Or should we instead prioritize broader developmental goals, in the spirit of what is sometimes called "Whole Child" education? The two sides of this debate are presented in this chapter by two fictional characters, Abraham and Sarah, to make it clear that neither of the actual authors of the chapter would endorse the strong version of the positions that are presented here. Nevertheless, the discussion will illuminate a question about goals that is centrally important to advancing the learning agenda in Jewish education.

Abraham: Let's start this conversation by picturing a real setting: A local day school, which is holding an event for prospective parents. In terms of its Jewish approach, the school is situated in what Arnie Eisen might call Judaism's "vital center." It could be a denominationally affiliated school, like a Schechter school, or a "community" school unaffiliated with a denomination. But enrollment is an issue, with the school needing to keep its numbers steady or growing. So tonight, the leaders and faculty have gone all out. Kids' art is up on the walls and their projects are displayed in the foyer. There's a new brochure, full of big, glossy photos of bright, shiny faces. The facility is spotless. 
Sarah: I can picture it. In fact, I think I've been in that very school!

Abraham: Right! Me too. So now, picture the head of school taking the microphone, as prospective parents settle into their seats. She's been readying her pitch for a week, writing and rewriting. "Welcome, parents!" she starts. "You've seen our modern facilities. You've seen the kids' art and their creative projects. Now let me tell you about our school's true strengths. If you send your kids here, I can guarantee you that they will learn a ton of Talmud. They'll be able to tell their amoraim from their elbows and their tannaim from their tucheses. They'll become Talmud readers extraordinaires." With this, the parents start to look at each other anxiously.

"But wait," the head continues, "I'm just getting going. They will also know so much Tanach you'll be completely blown away. We even teach Sefer Vayikra! And you should see how they score on our Jewish history exams!” By this point, if you and I are imagining similar parents and schools, you can hear the crickets chirping as the attendees start inching toward the door.

Why do parents send their kids to day school? Setting aside excellent general studies and wonderful college acceptance rates, they want things like "the development of personal Jewish meaning in the context of interaction with the secular world." ${ }^{1}$ Or they want their kids to make Jewish friends, or to build Jewish pride, or to instill whatever it is that makes it more likely that they will date and marry Jews. ${ }^{2}$ Or they want their children to develop lenses rooted in positive values - framed in a Jewish context - through which to view the worlds and themselves. Or they want their kids to develop parameters for making decisions, particularly those with ethical components (which covers a lot of ground, not limited to a sense of responsibility for others and tikkun olam, repairing the world); to come to see themselves within the flow of Jewish history; and to be prepared for "citizenship" within the current and emerging Jewish community. To use a term that has unreasonably fallen into disfavor, they may well want them to develop their identities, in general and specifically as Jews. Perhaps the most long-lived and wide-spread of all desired Jewish educational outcomes is for a child to become a mensch.

I just tossed out a lot of different ideas, each of which deserves serious consideration and critical development. Let me use the admittedly bulky term

1 Naava Frank, "A Judaic Curriculum for Jewish Day Schools: The Time is NOW," Contact: The Journal of the Jewish Life Network 4, no. 2 (2002), 12.

2 Steven M. Cohen and Shaul Kelner, "Why Jewish Parents Send Their Children to Day Schools," in Family Matters: Jewish Education in an Age of Choice, ed. Jack Wertheimer (Waltham, MA: Brandeis University Press, 2007), 80-100. 
"Jewish developmental outcomes" to refer to these and related outcomes. Perhaps not all of them are worthy. But my point is to highlight how different they sound from the kind of subject-specific outcomes that our imagined Head of School was talking about. And there's no reason to downplay these outcomes. These are the outcomes that most parents want, and these are the outcomes that Jewish educational institutions ought to focus on. Furthermore, if we really care about these Jewish developmental outcomes, we should make sure to assess our progress in promoting them among our students, and we should plan to intentionally and specifically address these outcomes in our education and not just assume that they will be a byproduct of learning.

Sarah: Thanks for painting that picture for us, Abraham. I agree that parents would not be excited by the pitch about how much Talmud the kids will learn. But I'm not sure that I draw the same conclusions from it that you do. In other words, I'm sure that a lot of parents would get turned off by excessive attention to academic subjects, especially if they're presented in dry and unexciting ways, just as you described. But that may tell us more about themand their sophistication as educational consumers - than it tells us about our desired outcomes.

Let me put my cards on the table. First, I believe that domain-neutral outcomes - the kind of "Jewish developmental outcomes" that you are talking about-are bogus, artificial constructions. We invent them, and then we turn around and we believe in them as if they're really real. And second, not only are they bogus, they're actually harmful.

What do I mean when I say that domain-neutral outcomes are bogus and artificial? I mean that they are invented for particular purposes. Psychologists and sociologists invent them because they want a quick-and-dirty way of capturing a whole set of phenomena. So, for example, rather than talking about a set of Jewish practices_ritual practices like candle-lighting on Shabbat and fasting on Yom Kippur, communal practices like giving to Federation, social network robustness like how many Jewish friends you have-the researchers can assemble an index of these various phenomena, and call it "Jewish identity." Some people do better on the index and some do less well. Before you know it, we're talking about Jewish identity as something that can be measured, that some people have more of than others. That's not a bad thing in itself. But there's no justification for turning the idea of "strengthening Jewish identity" into a goal of Jewish education.

The other purpose for inventing domain-neutral outcomes is more instrumental: some folks, namely philanthropists, want a way of comparing one 
domain to another. They are desperate to figure out some way to decide where to invest their money. Talmud classes teach Talmud. Israeli dance classes teach dance. How can you decide which one is better, more effective, a better use of resources? There has to be a domain-neutral metric that we can affirm, and that each domain tries to advance in its own way, right? That way, we can measure how well intervention $A$ does, in advancing toward metric $\mathrm{X}$, and how well intervention $\mathrm{B}$ does. By contrast, if $\mathrm{A}$ is advancing metric $\mathrm{X}$ and $\mathrm{B}$ is advancing metric $Y$, then we cannot measure them against each other. It's not surprising that Israeli dance classes teach more dance than Talmud classes do, and Talmud classes teach more Talmud than Israeli dance classes do. So there has to be something that we can point to, as the basis of comparison.

But that, I suggest, is a terrible argument. The fact that philanthropists need that domain-neutral metric to help them make their investment decisions is not good evidence that such a domain-neutral metric exists. Of course, it is often useful to look at a set of data and aggregate them in some way, to explain what they represent at a higher level of abstraction. But we have to remember that this is not a real thing. There is no "Jewish identity" muscle in the body, which then controls our candle-lighting and Federation-giving. And since there's no "Jewish identity" muscle, we shouldn't expect that Jewish education is going to strengthen it!

You know, thirty years ago, our teacher Lee Shulman developed a research project around domain-specificity with regard to teaching. ${ }^{3}$ To that point, teaching was mostly just considered a generic activity: you might be teaching math or history or home economics, but it was all basically the same. Shulman's argument, and his research, forced the field to recognize how absurd that was. He demanded that we pay attention to teachers' knowledge of specific subject areas and the particular ways they held that knowledge, proposing a new construct he called Pedagogical Content Knowledge. That was enormously important for how we think about the work of teaching, and especially, for how we think about the education of educators.

Subsequently, one of his leading students, Sam Wineburg, extended Shulman's inclination toward domain-specificity and focused on students, paying much more attention to what students know and are able to do within the specific domain of history. And once he did that, he grew increasingly impatient with our tendency to focus on domain-neutral capacities.

3 For example, Lee S. Shulman, “Those Who Understand: Knowledge Growth in Teaching," Educational Researcher 15, no. 2 (1986), 4-14. 
Consider his discussion of what's usually called "critical thinking," a topic that is notable mostly for how outlandish its claims are. Seriously-can you imagine that some folks believe that the way to promote critical thinking is to make students take Introduction to Logic? Although I suppose that's no more ridiculous than the belief that people will become better critical thinkers by studying art or poetry or other humanities.

Here's how Wineburg expresses his skepticism. "I really don't believe," he says, "that there are generic, domain-general, free-floating cognitive capacities that hover above a person's ability to read a poem, to solve a physics problem, to interpret historical documents, or to figure out infelicities of grammar in an essay." ${ }^{4}$ Poetry, physics, history, and grammar are substantively different from each other. They each have their characteristic challenges and puzzles, their characteristic intellectual moves, the traditions on which they call implicitly or explicitly. Engaging in the work of any of these fields does not entail the application of a generic disposition called "critical thinking." Rather, what students need is to develop sensitivity to these challenges, familiarity with these moves, and appreciation of these traditions.

Proponents of domain-neutrality often sound like they believe or imagine that there's a muscle called "critical thinking," or "Jewish identity," or "looking at the world through a Jewish lens," or something else, that operates across domains. Proponents of domain-specificity like me, on the other hand, think about domains like languages. We don't learn "language," we learn a specific language-first our native tongue, and then sometimes another one, and then another. You have to get good at each one, individually. Is it sometimes possible to transfer vocabulary or grammatical forms from one to another? Sure. But that's not domain-neutral learning. That's just drawing on one specific idea to help us understand another. So, fundamentally, we learn within specific domains rather than developing domain-neutral capacities.

Abraham: Wow, that's a rather sweeping dismissal of a whole body of literature in psychological development. You're using a pretty broad brush there, along with a rather narrow focus on cognitive abilities. Trust me, Sarah, I've got some things to say about this. But before I do, you also said that domain-neutrality is not just bogus but harmful. Can you explain what you meant by that?

4 Sam Wineburg, "Online Faculty Seminar Conversations On: A Conversation with Sam Wineburg," Virtual Knowledge Project, 2001, accessed November 7, 2008, http://crossroads.georgetown.edu/vkp/conversations/2001webcast/interview.html. 
Sarah: Of course. It's harmful because there's an unintended consequence that sometimes follows from a focus on domain-neutral outcomes and assessment of those outcomes. I think about that unintended consequence as the instrumentalization of Jewish education. Let me explain what I mean.

Once upon a time, in the 1980s and 90s, when "the Israel Experience" became a thing, we thought that sending kids to Israel was a good thing to do because we cared about Israel and we thought that kids should have a first-hand experience of Israel rather than just learning about Israel. To make the point a little more conceptually, we believed in that kind of knowledge and experience of Israel as part of our conception, our vision, of a robust and healthy Jewish life. First-hand experience of Israel was a Good Thing, with a capital G and a capital T. It had intrinsic value-not absolute value, of course, but still, relatively intrinsic.

But then Birthright came along. Not just the initiative itself, but also the research on it. I'm not criticizing the research, which is excellent methodologically. I'm pointing to an unintended consequence. Now that we have good research on what happens as a result of the trip, the whole way that we think and talk about the Israel experience has shifted. A decade into the Birthright research, a trip to Israel is good not for itself, not because first-hand experience of Israel is part of what it means to live a robust and healthy Jewish life, but rather because of what it produces ten or twenty years down the road-a Birthright bump of Jewish babies. For a lot of us, especially in the philanthropic community, the Israel trip is a means to that end.

That's part of what I mean by the instrumentalization of Jewish education. Once a Jewish educational mode or domain is conceptualized as a means to a domain-neutral end, then we stop assessing its merits and instead simply assess whether it is producing that other thing.

But that's not yet the harmful part. The harmful part is this: When we focus on domain-neutral outcomes, we disrupt the connection between the outcomes and the pedagogic practices that produce them. In the case of Birthright, when we focus on the domain-neutral outcome of more Jewish babies, we disrupt any connection between the outcome and the pedagogy of the Birthright trip - the careful sequencing of sites, the creation of spaces for reflection and group processing, the mifgash with Israeli peers, etc. All of that educational work by excellent and thoughtful practitioners is now devalued. So education becomes even more of a black box than it already is, and our research on outcomes cannot help to improve the quality of the education. 
Abraham: I'm with you on the concern about instrumentalization, but I think you're barking up the wrong tree. The problem of instrumentalization isn't necessarily linked to Jewish developmental outcomes. We can focus on the latter without falling into the former! But before I say more about that, your arguments have all been negative ones. It's time you said something about how subject-specificity avoids these problems.

Sarah: You're right! So let's talk about Talmud. Remember how you started this conversation by wondering who would possibly want to prioritize outcomes specific to the domain of Talmud? I readily accept that many parents in the kinds of schools that you were depicting are not going to get excited by a pitch about how much Talmud their kids are going to know. But there are other ways of thinking about this.

Let's imagine a teacher of Talmud who has a well-developed conception of the field, clearly articulated goals, and a very specific set of skills that she wants her students to learn. She teaches toward those goals, and she has developed a sophisticated assessment instrument, to find out whether her students have actually learned those subject-specific skills. This assessment is not like most superficial assessments: it's not about whether the students can repeat what they think she wants to hear, and it's not measuring whether they have learned in English class how to write a research paper (a skill that they are now expected to reproduce in Talmud class, with the result that it is mis-assessed as a Talmudspecific skill), and it's not about whether they have learned one of those fuzzy humanities skills like, say, "an openness to the diversity of the human experience." Those outcomes are all very nice but none of them are specific to this domain. Instead, this teacher is after something that really is domain-specific, like how the students read a passage in Talmud.

This might not seem so exciting to kids, or to parents. But here's the thing: The more she is focused on the subject-specific capacity, the better and sharper her planning will be, and the more focused and constructive her assessment will be. She will actually find out whether the students have learned what she wanted them to learn, and if they haven't, she will have to adjust her pedagogy accordingly. Moreover, she'll be able to articulate to the students what it is that they are actually learning, and if they work at it, what they'll be able to doand she'll be able to do that in a way that provides the kids with a sense of actual accomplishment within the domain. They will feel like they're making real progress toward clear, articulated goals. All of this is driven by specificity, by a refusal to resort to generic, domain-neutral goals that are disconnected from her pedagogy and difficult to assess responsibly. 
When we're thinking about this issue of domain-specificity or -neutrality, we might think about a non-academic domain like karate. When my kids were taking karate, it was crystal clear what they were supposed to be learning, and crystal clear, too, when they had learned it. There was a long, intense exam in which they had to actually perform the moves, and do them correctly. Not a lot of wiggle room: Can they do it or not? The outcome is domain-specific, and the assessment is too. That doesn't mean that karate is only about learning moves. It's a form of physical and mental training. It also teaches a certain mental and physical discipline. No one could or should deny this. As John Dewey ${ }^{5}$ wrote, there's always a lot of "collateral learning" that goes on, in any educational environment; we're never just learning one thing. At the same time, it's clear that there's a particular practice, with a particular focus. Nobody walks out of a karate class saying, "I don't know how to do any of the moves but I made a lot of progress this year in honoring the sensei." Honoring the sensei is valued-but that's not considered a success in the domain.

My claim is that domain-specificity can provide us with precise, concrete measures of accomplishment that are satisfying to learners and educators alike. I have in mind examples like testing for karate belts, or performing in the high school musical, or taking apart a sugya, or leyning a parashah. When we develop clear articulations of particular domains as domains of practice, we-as educators-are then able to plan learning experiences that help students to learn that practice, to get better at it, to find satisfaction in that growth, to demonstrate their learning in ways that feel authentic rather than contrived, and to move forward on the basis of those demonstrations to higher levels of the practice. And those kinds of assessments also tell us — as educators - how we're doing, too, in ways that enable us to improve our practice.

No Birthright educator will ever change her spiel on Masada because of the data on inmarriage among Birthright alumni. But domain-specific data? If that educator were to have access to those students' understanding of Jewish history and its significance? Well, that could make a difference to her spiel. In the end, that's why I believe that we should resist the siren song of domainneutrality, and instead, we should focus on domain-specificity in our educational practice and our scholarship.

Abraham: Got it. I think your point about a sense of accomplishment is particularly important; I think a lot about motivation for learning, and it seems clear to me that we need to do a better job of fostering intrinsic motivation of

5 John Dewey, Experience and Education (New York: Kappa Delta Pi, 1938), 48. 
the kind that flows from a sense of accomplishment. So I think you're on to something there. But, Sarah, I'm not sure that your karate example really proves your point that you want to make about domain-specificity. Perhaps increased "respect for the sensei" really is a valued outcome of karate class! If it is, then it should be an intentional part of instruction. And come to think of it, in a lot of dojos, it probably is. Moreover, it's not too hard to imagine that the karate teachers want this respect-for-teachers to persist beyond the dojo. They want those kids to learn something in karate that they will carry with them into their relationships with other teachers. In other words, it's a desired outcome, but it's what I would call a "developmental" outcome, not a domain-specific outcome.

Now, I certainly agree with you that that kind of transfer won't happen automatically. Some kids are totally respectful to their senseis, but somewhat less respectful to their rabbis. But that doesn't mean it can't happen. It needs to be reinforced and promoted - and, if it's really the desired outcome, assessedoutside of the dojo, beyond the karate domain. The point is, we can think about that respect as a cross-domain outcome that is probably much more important than the ability to break wooden boards with your forehead! We should not underestimate parents' wisdom about this.

There is a saying that I have heard attributed to both James Comer and Seymour Sarason, either of whom would be a worthy source. We can adapt it for our purposes. The saying goes: We don't teach math (or Talmud, or Bible), we teach children (or adolescents, or adults). The key "domain" of Jewish education is the developing learner, his or her set of dispositions, his or her ways of engaging with Judaism and the world at large, or whatever stand-in term for "identity" you want to use. When we teach math or Talmud or Bible, we are seeking to create learning opportunities for that developing person. We care about the specific subjects, sure, and we want to treat them with intellectual integrity, but in the end, they are all means to an end-not, as in the Birthright example, the goal of more Jewish babies, but the goal of a healthy Jewish life.

In that sense, Jewish education is instrumental. But this is not a criticism, because there's no reason to think any particular domain is inherently valuable - at least not when compared to the bigger, loftier goal of a healthy, flourishing life. This is what Maimonides proposed when, in the twelfth century, he declared that the purpose of the entire Torah is the improvement of the body and the improvement of the soul. If Talmud is a good thing, it's good because of how it helps people make sense of their lives, or fixes their moral compass, or grounds them in the literature of their civilization, or something 
like that. Those are the things we really care about, and they transcend particular domains.

Furthermore, Sarah, what do you even mean, when you talk about domains? You seem to be proposing a surprisingly sharp differentiation between the various academic disciplines. Sure, the way one studies Talmud is different than the way one studies other subjects, in certain respects, but students of Talmud are also, inevitably, students of Hebrew and Aramaic language, and students of Bible and biblical interpretation, and students of Jewish history, and students of law, and students of folklore, and on and on-all at the same time. You can't avoid crossing domains. How could Jewish history, for example, be irrelevant? For that matter, how can Sassanian Persian history - the history of the period when the Talmud was composed in the Persian Empire-be irrelevant to the study of Talmud? I'm not arguing that every Jewish day school class in Talmud should also include Sassanian history. I'm just wondering how you can be so confident about the boundaries around these domains.

In fact, in many schools, these boundaries are collapsing because thoughtful practitioners are re-examining their assumptions about Jewish studies disciplines, or just under the weight of time constraints, so that a single integrated "Judaics" course is becoming the norm.

But even putting that aside, do these distinctions mean anything to the students? And, isn't there more than a little arbitrariness? Don't we want students to walk away not only with knowledge of these fragmented subjects, but also with a big picture of how they are related to each other? That what we call Rabbinics, for example, is deeply related to Tanakh and takes place at a particular moment (or moments) of Jewish history? Or that there is a value system woven throughout the tradition? Don't we want students to find relevance and meaning in this tradition as it plays out outside of the classroom? And, don't forget that a lot of learning in schools happens outside of formal domain-based settings. Where in a domain-specific approach do we account for what students take-away from Shabbatonim, for example? In what domain do we file the feelings that accompany the celebration of Shabbat with their friends?

Imagine if a school worked as a cohesive whole to articulate these developmental outcomes, and to achieve them. It would mean mapping the curricular and co-curricular activities against social and emotional Jewish outcomes that cross domains. The result would be a way into seeing one's self and the world through a Jewishly informed lens. How much did their Talmud class contribute to such an outcome? Their Bible class? Their participation in a Shabbaton? These may be interesting questions to study, but they are all secondary to the 
basic question of whether students are developing a Jewisly informed way of thinking of themselves and the world, a set of outcomes that cannot be pegged to a domain. If students are intentional about their eating habits because they remember the theme of bal tashchit, the biblical prohibition against wasting resources, does it really matter if they learned it mostly in Talmud class, or on a field trip to a food pantry? Or, if they feel a sense of empowerment or agency in Jewish spaces, does it matter if that happens because they learned how to lead Tefillah or because they organized the senior Shabbaton?

Reifying these domain divisions may actually work against our goal of an integrated understanding of Judaism, and create a disconnect between the classroom and the real world. Research in general education suggests that students generally do not automatically weave disparate subject matters into a common narrative; and research in Jewish schools suggests that there are rarely efforts to connect discussion of "content" with Jewish developmental outcomes. Now that can be harmful!

Sarah: But doesn't domain-specific learning result in the sort of outcomes you are describing?

Abraham: Domain-based learning can have a role to play, for sure, but it's only part of the story. Jewish developmental outcomes transcend individual subject areas, and deep subject matter proficiency is certainly not sufficient for the achievement of these outcomes. We all know that there are plenty of disaffected day school graduates who learned a lot of Bible and Rabbinics. And, even if someone develops a sense of connectedness to a subject area, such as Jewish history or Tanakh, there is no reason to think that this would generalize to anything beyond their relationship with that subject area. In fact, I believe you argued that there is every reason to be suspicious of such generalizations!

Sarah: Alright, maybe specific subject matter knowledge is not sufficient. You are certainly correct that there's no guarantee that doing well in Talmud class will lead to a thriving Jewish life - although maybe that's always going to be the case, because education is not the kind of thing where we should look for guarantees. But in any case, perhaps we can say that specific subject matter knowledge is a necessary prerequisite?

Abraham: I'm not so sure. Can one develop a Jewishly informed framework for understanding one's self and the world without deep content knowledge? I certainly know people who know enough to have Judaism inform their decisions and lives, but are far from what we might consider content experts. What they "know" is more about a way of being in the world. They know who they are, in deep ways, even if they cannot read Talmud. Actually, I often wonder if 
our fetishizing of content knowledge results in distancing and barriers, with people being discouraged from Jewish involvement because the knowledge barriers to entry are perceived as too high; they are concerned they will seem stupid or inept. While one might say this is an argument for focusing on subject knowledge, to help people overcome the barriers, there is at least as much argument for lowering the barriers, and finding meaningful pathways into Judaism that match people's strengths and passions. To an extent, this may already be happening - look at the blossoming of niche expressions of Judaism.

Sarah: Interesting. I suspect that if we teased out some examples, we would find that these folks whom you're referring to actually do know a lot, about some specific domains that are important to them. It might be the domain of Jewish holiday cooking or something equally "popular," rather than an elite or intellectual domain. And it may have been learned through osmosis or mimicry, rather than in a classroom. But it's still an important domain.

But let's set that aside for a moment, because I want to press you on the assessment question. Even if we value these domain neutral outcomes, what good is it, pedagogically speaking, if we can't assess them? Anybody can say that they're teaching menschlichkeit or moral behavior, or promoting a positive Jewish identity, or something else that sounds vaguely developmental. Aren't you worried that it all becomes smoke and mirrors?

Abraham: Well, look, it's definitely easier to assess cognitive or knowledge-based domain-specific growth that it is to assess outcomes in the Jewish developmental realm. But that hardly seems like a rationale for ignoring the latter. Perhaps you have heard the parable: A person is crawling around at night under a streetlight. A passerby asks if there is a problem, and the crawler responds, "I lost my keys and I am trying to find them." This story must have taken place before the days of ubiquitous cell-phone flashlights! Anyway, the passerby joins in the search, but eventually grows frustrated and asks, "Are you sure you dropped them here?" "No," comes the reply, "I know I dropped them down the block, but I'm looking here because the light is better." That's what happens when we allow assessment to drive goals, rather than determining our goals first and then figuring out how to assess as responsibly as we can. We should definitely be working to develop better assessments, not letting the current limitations drive our pedagogical efforts. But it's not impossible. There are some really interesting assessments that have been developed for related secular outcomes, as well as outcomes in Christian education. Are they perfect? No. But no assessment is. 
Here's how I want to wrap up, Sarah. I believe, and I expect that you do too, that a Jewish education should prepare Jews to participate in contemporary Judaism. But what does it take to participate in contemporary Judaism? Being a Jew today means being to some extent countercultural and to some extent multicultural. Take the decision, for example, to celebrate Shabbatwhether it is an unplugged, tech-free day, or going to synagogue, or something else. What kind of Jewish education supports that decision?

If you're thinking primarily about academic Jewish studies subject areas, about those "domains," then you might answer that students need to know the relevant portions of Masechet Shabbat from the sixth century, or Maimonides' Mishnah Torah from the twelfth, or Kagan's Mishnah Berurah from the twentieth. But as lovely as it is when Jews are comfortable exploring those texts on their own, I don't actually think that's what most Jews really need to support Shabbat as a practice in their lives.

Instead, I want to argue for the importance of outcomes that don't sit comfortably within a particular domain. For example, they should understand the intersections of Jewish thought and text to perennial societal problems. They should have practice negotiating the conflict of commitments that emerge from living with multiple identities, between cultural norms, as well as negotiating Judaism's tensions between particularism and universalism, and communalism and individualism. They should have developed a stance on the nature of obligation in an era of choice. They should have experience with the joy and meaning of living within community. Any of these, I propose, are actually more important to how a Jew decides to live, and what she decides to do with her Saturdays, than whether she knows the thirty-nine categories of forbidden work, as delineated in Masechet Shabbat.

These Jewish developmental outcomes are not subject-specific, but they're not exactly subject-neutral either. They transcend subject matter divisions and should be addressed and assessed as such.

Sarah: That's a really compelling argument, Abraham. I appreciate you're keeping your eyes on the prize, which is helping students to live happier, healthier, more robust Jewish lives. And I'm particularly intrigued by your suggestion, at the end, that the kinds of developmental outcomes that would really make a difference to individuals are not, actually, subject-neutral. In other words, even though I've been thinking about a dichotomy between subject-specificity and subject-neutrality, I hear you saying that some of our debate may be resolved by thinking differently about how to characterize specific domains that we really care about, rather than just assuming that they map onto the traditional academic subjects. 
But here's my final thought. If you ask me why I really care about the issues that we've been talking about, it's not the case that I want a relentlessly cognitivist education that will end up being meaningless to the students-or worse than meaningless. On the contrary, I want to encourage Jewish educational practitioners to structure their curricula so that they will be deeply meaningful to students. And I believe that the way to do that is to do real, serious work on something of value, in a way that makes sense to students and that leads to a sense of real accomplishment and even mastery. They should learn to enact a practice, or more than one, and to do so well. They should learn a cultural performance, or more than one. They should not just feel that they are marking time or, as Denise Clark Pope ${ }^{6}$ put it, "doing school."

I might even be willing to say that that's the non-domain-specific Jewish developmental outcome that I'm after-a sense of accomplishment, of mastery, of ownership of a domain or a practice that is culturally valued and which the student has come to value. If that's where we're headed, I don't actually care whether the domain is Talmud or Tanakh or Hebrew, or reading Torah, or Israeli dance or contemporary Israeli pop music, or Jewish social action, or something else entirely. Surely some students will gravitate to some domains and other students will gravitate to others. That's fine! But at the moment, I worry that, for many of our students, they spend years in a day school or other venues without ever having any sense of accomplishment at all. They've never gotten really good at anything. They've never owned any particular domain. They've never gotten the sense that they are on a trajectory, with compelling role models for mastery in the domain whom they want to emulate.

Our teacher Michael Rosenak wrote frequently about Jewish education as the teaching of Jewish language, through the medium of Jewish literature. I find this a really important metaphor, so long as we remember that there's more than one Jewish language — by which I mean not just Hebrew and Yiddish and Ladino and others, but also, the language of Jewish religious ritual and the language of Jewish philosophy and the language of contemporary Israeli culture. The reason the metaphor of languages-and-literatures is compelling is that it reminds us that, at its best, Jewish education can be a process of learning how to actually do something, to become fluent or adept or capable, to get inside of some domain or practice, and thereby to join a community of other people who also speak that language. That community preceded me, so this practice of

6 Denise C. Pope, Doing School: How We Are Creating a Generation of Stressed-Out, Materialistic, and Miseducated Students (New Haven, CT: Yale University Press, 2003). 
language-speaking is not idiosyncratic to me and I don't just get to make stuff up. And it's also the case that the community will continue after I'm gone, so I feel some sense of responsibility to contribute to the conversation, to keep it going in interesting ways.

So thanks, Abraham, for participating with me in that most Jewish practice, the practice of arguing! But not just any argument. To make it an authentically Jewish practice, it should be what the tradition calls a mahloket le-shem shamayim, an "argument for the sake of Heaven," an argument about the things that really matter. Which is really what we've been talking about all along: what really matters in Jewish education. 


\section{Bibliography}

Cohen, Steven M., and Shaul Kelner. "Why Jewish Parents Send Their Children to Day Schools." In Family Matters: Jewish Education in an Age of Choice, edited by Jack Wertheimer, 80-100. Waltham, MA: Brandeis University Press, 2007.

Dewey, John. Experience and Education. New York: Kappa Delta Pi, 1938.

Frank, Naava. "A Judaic Curriculum for Jewish Day Schools: The Time is NOW." Contact: The Journal of the Jewish Life Network 4, no. 2 (2002), 12-13.

Pope, Denise C. Doing School: How We Are Creating a Generation of Stressed-Out, Materialistic, and Miseducated Students. New Haven, CT: Yale University Press, 2003.

Shulman, Lee S. "Those Who Understand: Knowledge Growth in Teaching." Educational Researcher 15, no. 2 (1986), 4-14.

Wineburg, Sam. "Online Faculty Seminar Conversations On: A Conversation with Sam Wineburg.” Virtual Knowledge Project, 2001. Accessed November 7, 2008. http://crossroads.georgetown.edu/vkp/conversations/2001webcast/interview.html. 